\title{
Limnological study on a newly built drinking water reservoir near Tirana, Albania
}

Çullaj, A ; Duka, S ; Emiri, A ; Koni, E ; Miho, A ; Murtaj, B ; Shumka, S ; Bachofen, R ; Schanz, F ; Brandl, $\mathrm{H}$

\begin{abstract}
Bovilla Lake is a reservoir constructed 12 years ago for supplying the city of Tirana (Albania) mainly with drinking water. It has a surface area of $4.6 \mathrm{~km} 2$, a maximum depth of originally $60 \mathrm{~m}$ and is monomictic with a stratification period from early spring to end of October. The lake is oligotrophic with low nutrient concentrations (e.g. SRP in spring about $8 \mathrm{~g} \mathrm{~L}-1$ ) and minor oxygen depletion in the hypolimnion during thermal stagnation. The lake is highly turbid due to severe particle import by several rivers during rain periods. This led to a massive deposition of sediments, lifting the maximum depth to $45 \mathrm{~m}$ in 2008. Furthermore, the photic zone reached hardly more than $10 \mathrm{~m}$. Algal species diversity is high; however, diatoms from the genus Cyclotella dominate most of the year both in numbers and biomass. Our study describes for the first time the hydrography and limnology of the Bovilla Reservoir.
\end{abstract}

DOI: https://doi.org/10.1007/s10661-010-1871-z

Posted at the Zurich Open Repository and Archive, University of Zurich

ZORA URL: https://doi.org/10.5167/uzh-45269

Journal Article

Published Version

Originally published at:

Çullaj, A; Duka, S; Emiri, A; Koni, E; Miho, A; Murtaj, B; Shumka, S; Bachofen, R; Schanz, F; Brandl, H (2011). Limnological study on a newly built drinking water reservoir near Tirana, Albania. Environmental Monitoring and Assessment, 182(1-4):215-232.

DOI: https://doi.org/10.1007/s10661-010-1871-z 


\title{
Limnological study on a newly built drinking water reservoir near Tirana, Albania
}

\author{
Alqiviadh Çullaj • Sonila Duka • Artan Emiri • Erlinda Koni • Aleko Miho • \\ Bledar Murtaj • Spase Shumka • Reinhard Bachofen • \\ Ferdinand Schanz • Helmut Brandl
}

Received: 18 May 2010 / Accepted: 28 December 2010 / Published online: 14 January 2011

(C) Springer Science+Business Media B.V. 2011

\begin{abstract}
Bovilla Lake is a reservoir constructed 12 years ago for supplying the city of Tirana (Albania) mainly with drinking water. It has a surface area of $4.6 \mathrm{~km}^{2}$, a maximum depth of originally $60 \mathrm{~m}$ and is monomictic with a stratification
\end{abstract}

Electronic supplementary material The online version of this article (doi:10.1007/s10661-010-1871-z) contains supplementary material, which is available to authorized users.

A. Çullaj · S. Duka Chemistry, Faculty of Natural Sciences, University of Tirana, Tirana, Albania
A. Çullaj
e-mail: acullaj@albmail.com
S. Duka
e-mail: soniladuka@hotmail.com

\author{
A. Emiri \\ Drinking Water Treatment Plant, Kodra Kuqe, \\ Tirana, Albania \\ e-mail: edasulaj@live.com \\ E. Koni \\ Institute of Veterinary Food Security, Tirana, Albania \\ e-mail: erlindakoni@yahoo.com
}
A. Miho
Biology, Faculty of Natural Sciences, University
of Tirana, Tirana, Albania
e-mail: aleko.miho@unitir.edu.al

period from early spring to end of October. The lake is oligotrophic with low nutrient concentrations (e.g. SRP in spring about $8 \mu \mathrm{g} \mathrm{L}^{-1}$ ) and minor oxygen depletion in the hypolimnion during thermal stagnation. The lake is highly turbid due to severe particle import by several rivers during rain periods. This led to a massive deposition of sediments, lifting the maximum depth to $45 \mathrm{~m}$ in 2008. Furthermore, the photic zone reached hardly more than $10 \mathrm{~m}$. Algal species diversity is high; however, diatoms from the genus Cyclotella

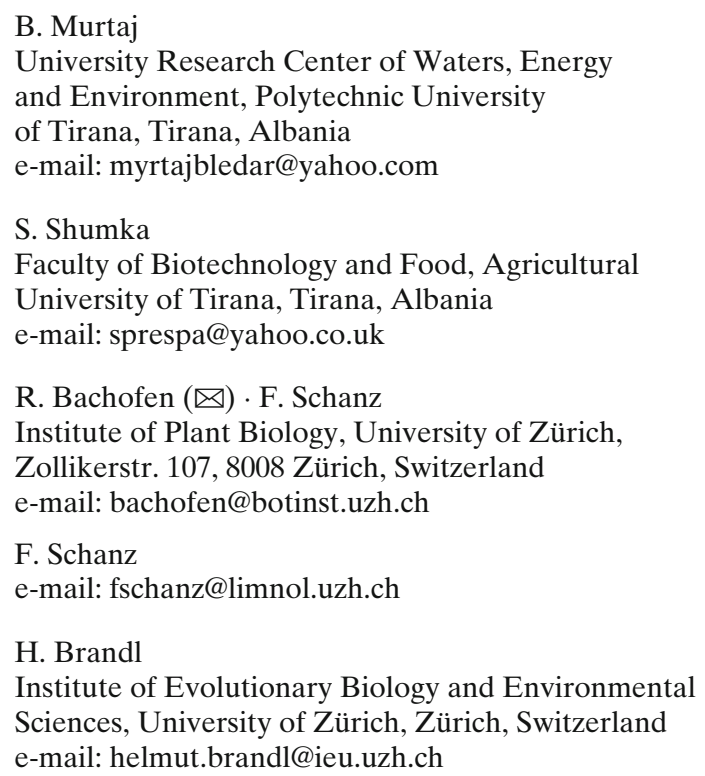


dominate most of the year both in numbers and biomass. Our study describes for the first time the hydrography and limnology of the Bovilla Reservoir.

Keywords Bovilla Reservoir •

Drinking water supply $\cdot$ Turbidity $\cdot$ Oligotrophy • Suspended material $\cdot$ Cyclotella

\section{Introduction}

Water is essential for all life. It represents a basic human right and worldwide an important component of an effective policy for health protection as well as a development issue at a local, national and international level. In the Mediterranean climate with a regime of dry and warm weather during the summer months and moderate precipitation during late autumn, winter and early spring, reservoirs are important during summer to supply sufficient drinking water and water for irrigation in agriculture. The quality of the reservoir water depends on the nutrient level, chemical characteristics and the particle load of the input rivers and the activities of benthic and pelagic organisms within the lake itself. Many factors influence the quality of the water in the reservoir directly or indirectly, such as climate, soil structure, vegeta- tion, land slope, lake morphometry, water level fluctuations and human activities in the catchment area. The present study describes the limnological properties of Bovilla Lake, a recently built reservoir for the drinking water supply of Tirana.

Tirana, the capital of Albania, is a town with an extreme rapid population increase. While it counted about 250,000 inhabitants in 1990 , the population increased to 350,000 in 2001 and officially to 600,000 in 2008 (INSTAT 2010). Today, the population is estimated to be over 850,000 inhabitants. Up to the end of the last century, the drinking water of Tirana originated from springs and groundwater (min. $1.2 \mathrm{~m}^{3} \mathrm{~s}^{-1}$, max. $2.3 \mathrm{~m}^{3} \mathrm{~s}^{-1}$ ), which was collected in tanks located at different sites around the city with a total capacity of about $67,600 \mathrm{~m}^{3}$ (Table 1). In 1997, the water supply in Tirana was in an alarming situation; the distribution system allowed water availability in households for only a few hours per day. Furthermore, in certain parts of the town, it was contaminated with fecal coliforms. Water loss in the distribution net reached up to $40 \%$ and several water-borne diseases have been reported (Palombi et al. 2001). In summer 2006, over 250 Hepatitis B cases were reported. In addition, overchlorination of the water resulted in a broad range of halogenated compounds (Floqi 2007).

To overcome an increasing shortage of drinking water described above, the Bovilla reservoir was
Table 1 Drinking water resources in Tirana (Albania) in 2006 (adapted from Floqi 2007)

\begin{tabular}{llll}
\hline Type & Location & $\begin{array}{l}\text { Approximate } \\
\text { flow }\left(\mathrm{m}^{3} \mathrm{~s}^{-1}\right)\end{array}$ & $\begin{array}{l}\text { Sum of each } \\
\text { group }\left(\mathrm{m}^{3} \mathrm{~s}^{-1}\right)\end{array}$ \\
\hline Natural springs & Selita & 0.3 to 0.7 & \\
& Shen Meria & 0.3 to 0.7 & \\
Groundwater (wells) & Old Bovilla & 0.14 to 0.44 & 0.74 to 1.84 \\
& Laknasi & 0.15 & \\
& Bërxulla & 0.16 & \\
& Buka & 0.03 & \\
& Pema & 0.03 & \\
& Coca Cola & 0.03 & \\
& Pishina & 0.01 & 0.46 \\
& Kroi Shen Gjini & 0.02 & 1.8 \\
& Çokollata & 0.02 & 4.1 \\
\hline Surface water & Yzberishti & 0.01 & \\
Total maximum available water & Bovilla reservoir & 1.8 & \\
\hline
\end{tabular}


planned. The construction of the dam started in 1988, and the work was completed after several interruptions in 1996 (Gjata 1997). The dam was placed in a steep and narrow gorge of Terkuza River (Fig. 1a), situated about $15 \mathrm{~km}$ North-East of Tirana city (Fig. 1b). The water reservoir was filled in 1998, and in 1999, the water from Bovilla Reservoir started to be used as the main drinking water source for the city of Tirana. At the same time, the drinking water treatment plant in Kodra Kuqe (Tirana) went into operation, connected with the Bovilla Reservoir by a steel pressure line of about $10 \mathrm{~km}$ in length with a capacity of up to $1.8 \mathrm{~m}^{3} \mathrm{~s}^{-1}$. The Bovilla watershed area extends in the Northeast of Tirana between $41^{\circ} 30^{\prime} \mathrm{N}$ and $41^{\circ} 15^{\prime} \mathrm{S}$ and $19^{\circ} 50^{\prime} \mathrm{W}$ and $20^{\circ} 05^{\prime} \mathrm{E}$.
Fig. 1 Topographic map of Bovilla Reservoir (a) (adapted from

Anonymous 1996) with the three sampling sites, $S 1, S 2$ and $S 3$, main inflow and outflow (Terkuza River) marked with arrow, and $\mathbf{b}$ map of the Tirana region (adapted from Gloyer 2004)

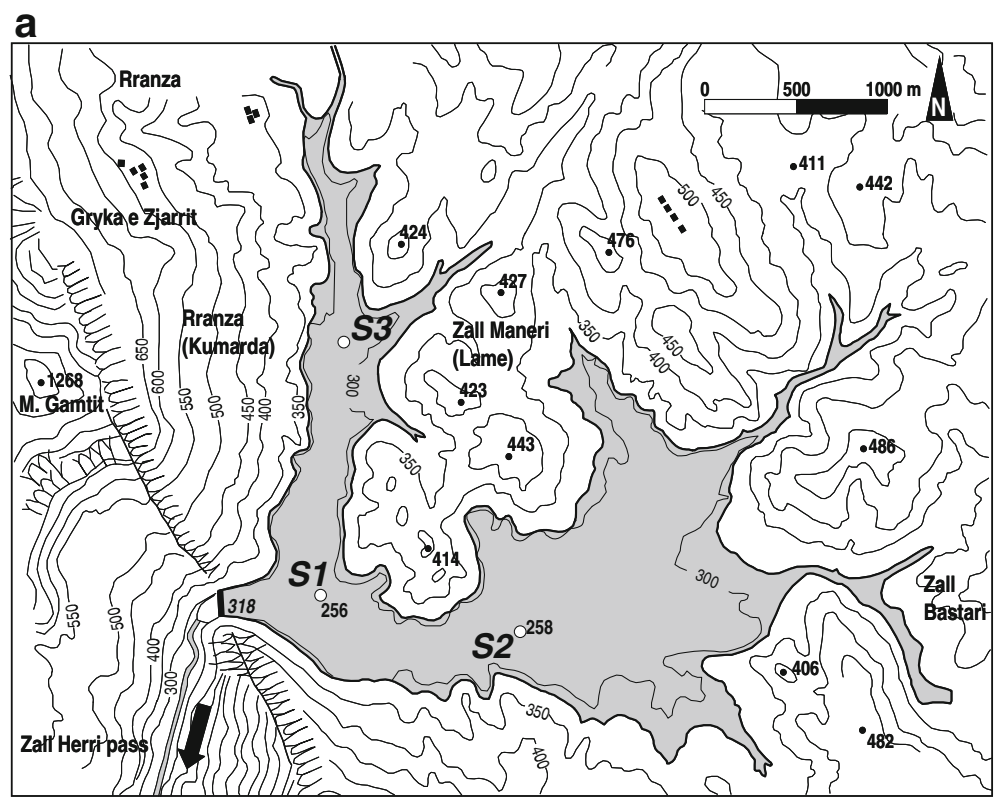

b

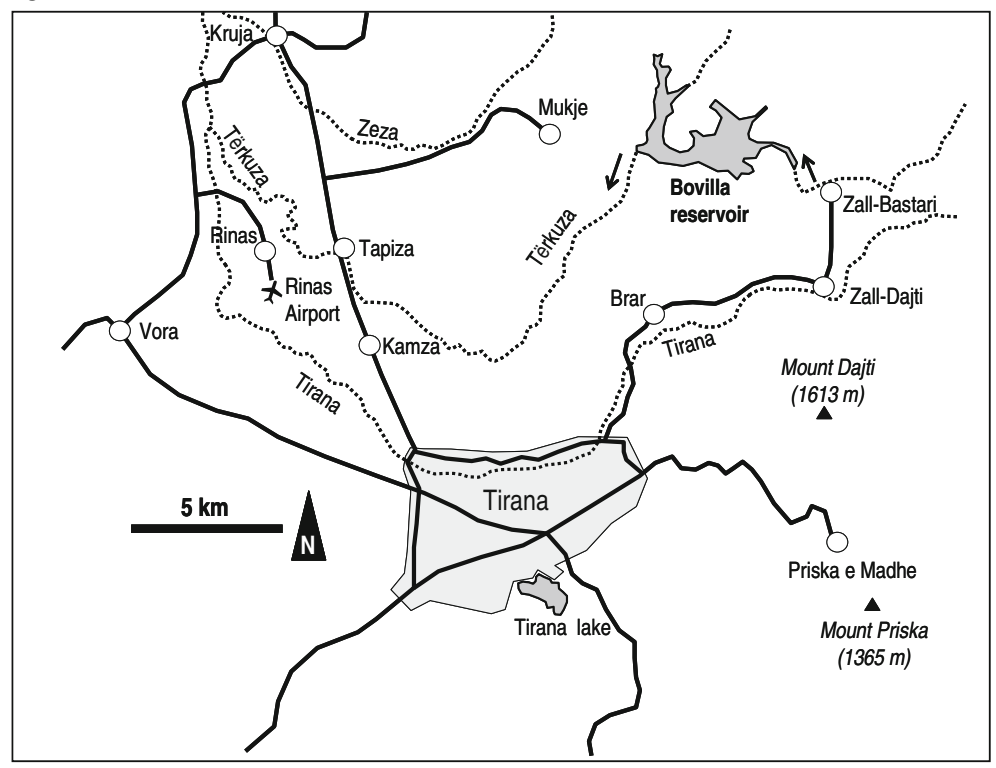


The Bovilla Reservoir is one of the largest hydro-technical constructions in Albania. The surface area of the reservoir is $4.6 \mathrm{~km}^{2}$; its average depth $18 \mathrm{~m}$. The calculated maximal depth after the impoundment was $60 \mathrm{~m}$, but it did not extend to more than $45 \mathrm{~m}$ during our study. The maximal capacity is about $80 \times 10^{6} \mathrm{~m}^{3}$ when the surface level is at $318 \mathrm{~m}$ a.s.l. The drainage area of the Bovilla Reservoir covers approximately $98 \mathrm{~km}^{2}$ and provides the lake with an average water inflow of $3.3 \mathrm{~m}^{3} \mathrm{~s}^{-1}$. The main river Terkuza delivers a total discharge of about $50 \times 10^{6} \mathrm{~m}^{3}$ year $^{-1}$ (equal $1.6 \mathrm{~m}^{3} \mathrm{~s}^{-1}$ ). Eroded slopes in this mountainous area are quite common; after rainfall the rivers bring masses of fine material into the lake, leading to a rapid increase of the sediment volume. In contrast to many dammed reservoirs, Bovilla Lake is not canyon shaped and its theoretical water residence time is about 1 year.

There are no important point source discharges and no significant non-point sources delivering pollutants into the lake. The watershed is covered with forests and agricultural land and only a few villages are within the catchment area.

The Bovilla catchment area belongs to the hilly Mediterranean climate, with heavy precipitations (pluriannual average of 1,200-1,300 mm year ${ }^{-1}$ ) mainly during the end of winter and end of autumn (Kabo 1990-91). During 2006 to 2008, the period of the present investigation, the total rainfall was distinctly higher in the years 2006 and 2007, amounting for about 2,027 and 1,740 mm, respectively, while in 2008 , it was close to the longtime average with $1,154 \mathrm{~mm}$.

Shortly after the impoundment in autumn 2001, an earthy unpleasant smell and taste appeared in the drinking water. However, up to now, the exact source of it stays still unknown. Such smell and taste phenomena are well known worldwide in many lakes (Jüttner and Watson 2007; Schulz and Dickschat 2007). To eliminate the nuisance, expensive adsorption steps with active carbon had to be included in the treatment of the water.

It is the goal of every lake management to maintain the high quality of the water used for drinking purpose. This, however, is not so important for the water used for irrigation. It is often observed that newly built reservoirs become rapidly eutrophic after the impoundment due to the input of nutrients from nutrient-rich soils in the catchment and from the decomposition of organic material left in the lake, with the consequences of increased algal growth, loss of oxygen in the hypolimnion, emergence of undesirable smell, taste and color, loss of reservoir volume due to a high silt load and high costs for the treatment of the drinking water.

The goal of the present study was (1) to describe for the first time the hydrography and the limnology of the Bovilla Reservoir, (2) to determine the limiting factors for biomass production and (3) to define those lake parameters which correlate with or might be responsible for the outbreak of the undesired smell and taste phenomenon and which could act as a first warning system to control the costly elimination process in the treatment plant. The presented work has been achieved by several independent scientific groups of Albania in cooperation with scientists from Switzerland. The detailed analytical data have been reported and discussed separately in Albanian by each participating group (Miho et al. 2009a, b).

\section{Materials and methods}

Water was collected bimonthly between May 2006 and September 2008 at 1, 3, 5, 10, 15, 20, 30 and $40 \mathrm{~m}$ depth using a Ruttner 2-L bottle. Samples were taken for the first year at three sites (S1, S2, S3, Fig. 1a), later only at the site of the greatest depth (S1), as the data on water chemistry at the three stations were nearly identical. The differences in the profiles of temperature, oxygen concentration and turbidity between the three sites were checked by the Kruskal-Wallis test and found except for few erratic single months to be not significantly different.

Access to the lake was troublesome on an unpaved mountain road. The following physicochemical parameters were analyzed using standard procedures (Miho et al. 2009a, b):

Temperature $\left({ }^{\circ} \mathrm{C}\right), \mathrm{pH}$ and Conductivity $\left(\mu \mathrm{S} \mathrm{cm}^{-1}\right)$ (APHA 1988), Turbidity (NTU) (WTW Turb 430), Secchi-Disk-Transparency (m) (Secchi disc), Oxy- 
gen concentration $\left(\mathrm{mg} \mathrm{L}^{-1}\right)$ and $\mathrm{BOD}_{5}\left(\mathrm{mg} \mathrm{L}^{-1}\right)$ (Winkler, APHA 1988, 421A, 507), Alkalinity $\left(\mathrm{mg} \mathrm{CaCO}_{3} \mathrm{~L}^{-1}\right.$ ) (APHA 1988, 403), Total Organic Carbon (TOC, mg L ${ }^{-1}$ ) (HACH), UVA Absorbency at $253.7 \mathrm{~nm}\left(\mathrm{~cm}^{-1}\right)$ (APHA 1988, 5910B), Oxidizability as permanganateconsumption $\left(\mathrm{KMnO}_{4}\right)\left(\mathrm{mg} \mathrm{L}{ }^{-1}\right)$ (ISO 8667), total suspended solids (TSS, mg L ${ }^{-1}$ ) (APHA 1988). Nitrogen and phosphorus as main nutrients: Phosphate $\mathrm{PO}_{4}^{-3}-\mathrm{P}\left(\mu \mathrm{g} \mathrm{L}^{-1}\right)$ (APHA 1988, 434F), Nitrate $\mathrm{NO}_{3}^{-}-\mathrm{N}\left(\mu \mathrm{g} \mathrm{L}^{-1}\right)$ (APHA 1988, 418A), Nitrite $\mathrm{NO}_{2}^{-}-\mathrm{N}\left(\mu \mathrm{g} \mathrm{L}{ }^{-1}\right)$ (APHA 1988, 419), and Ammonium $\mathrm{NH}_{4}^{+}-\mathrm{N}\left(\mu \mathrm{g} \mathrm{L}^{-1}\right)$ (APHA 1988, 417C). The photosynthetic pigments (chlorophyll $a, b, c$, phaeophytin, $\mu \mathrm{g} \mathrm{\textrm {L } ^ { - 1 }}$ ) were analyzed by spectrophotometry (APHA 1988, 10200H) and the trace metals iron and zinc $\left(\mu \mathrm{g} \mathrm{L}^{-1}\right)$ by atomic absorption spectrophotometry (Varian 10+ SpectrAA).

The phytoplankton and the zooplankton were qualitatively and quantitatively characterized (cells or individuals $\mathrm{mL}^{-1}$ ) (Utermöhl 1958), using an inverted microscope Zeiss Axiovert 25; the microbiology concerned the quantification of total coli, fecal coli and fecal streptococci, using membrane filtering $(0.45 \mu \mathrm{m})$ and cultivation techniques (APHA 1988; EU directive 75/440). A detailed description of the methods is given in Miho et al. (2009a, b).

\section{Results}

Hydrology

As in many reservoirs for drinking water or power generation, the water level in Bovilla strongly oscillates over the season; during the study period 2006-2008, the oscillation of the water level amounted for up to $7 \mathrm{~m}$ (Fig. 2). The maximum level was observed during the rain period (February-April), due to the excess hydraulic loading from the watershed. The minimum appeared at late summer to autumn (OctoberNovember) as the result of the scarce rainfall in the region and the excessive use of water for drinking and irrigation purposes. The year 2007 had extraordinary rain events in May which did not reflect in the lake level. It must be kept in mind, that the precipitation records come from Dajti Mountain situated about $5 \mathrm{~km} \mathrm{SE}$ from Bovilla and outside of its catchment area (Fig. 1b). Monthly water consumptions were quite constant over the seasons, as water for irrigation in agriculture is withdrawn from the lake parallel to the water treatment plant. There is a significant negative linear relation between the amount of water taken from the lake and its level. In dammed reservoirs heavy rainfall may often induce a higher flushing of the reservoir bed and influence the biological
Fig. 2 Hydrological data of Bovilla Lake during 2006 to 2008: monthly mean values of rainfall (bars), water consumption by the WTP (open circles), water level of reservoir (open triangles) and air temperature (filled circles)

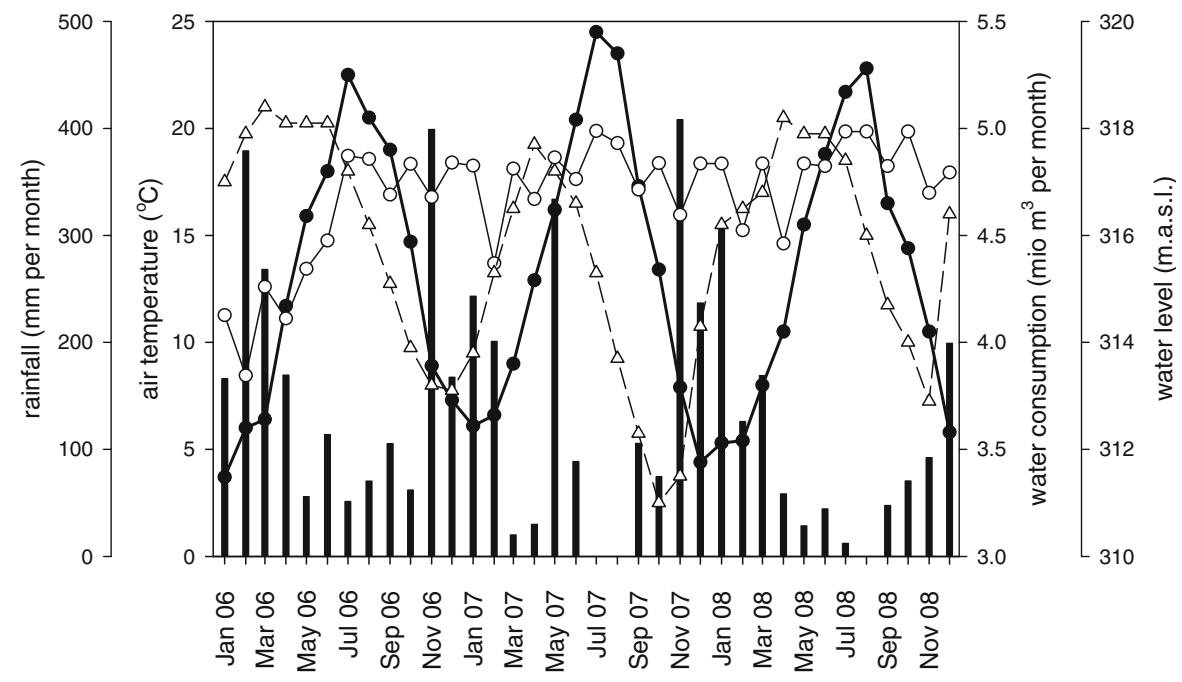


lake system; the ratio of lake volume to input by the tributaries suggests that Bovilla is in a hydraulic steady state equilibrium. Changes in the water level in a reservoir may influence the water quality, and it must be taken into consideration for a proper management of the water resource. However, in a V-shaped basin as in Bovilla Lake, the volume development $D_{\mathrm{v}}$ (Hutchinson 1957) is small, thus water quality is barely influenced by surface level depression and the ratio between sediment surface and water volume changes not considerably (see Miho et al. 2009a, b, Figs. 1, $2,3,4,5$, and 6). Therefore the influence of the sediment on the water body does not increase significantly.

Physicochemical and chemical characterization of Bovilla Reservoir

The Bovilla Reservoir is a temperate monomictic lake (Wetzel 2001), as demonstrated by the temperature profiles (Fig. 3a). It does not freeze in winter and is thermally stratified during the summer season from about March to October. In 2006, the epilimnion extended down to $5 \mathrm{~m}$ depth (2007: $10 \mathrm{~m})$, with a thermocline between 5 and $10 \mathrm{~m}$ (2007: 10 and $15 \mathrm{~m}$ ); in the hypolimnion, temperatures stayed between $7.6^{\circ} \mathrm{C}$ and $11.2^{\circ} \mathrm{C}$. During winter, the lake became fully mixed, with temperatures of $8^{\circ} \mathrm{C}(13 / 1 / 2007), 11^{\circ} \mathrm{C}(25 / 11 / 2007)$ and $7.6^{\circ} \mathrm{C}(18 / 1 / 2008)$ within the whole water column.

The yearly cycle from stratification to mixis in the Bovilla Reservoir is also reflected in the water profiles of the oxygen concentrations. During summer stratification, the oxygen concentration in the hypolimnion $(40 \mathrm{~m})$ dropped to $6 \mathrm{mg} \mathrm{L}^{-1}$ while the epilimnion occasionally became slightly oversaturated (up to $11 \mathrm{mg} \mathrm{L}^{-1}$ at 1 and $3 \mathrm{~m}$ depth), due to photosynthetic processes (Fig. 3b). The limited oxygen loss in the hypolimnion and the small oversaturation indicates a mainly oligotrophic situation. Photosynthesis in the epilimnion and the degradation of organic compounds in deeper layers were also reflected in the dynamics of the $\mathrm{pH}$; while in the epilimnion, $\mathrm{pH}$ values up to 8.5 were observed, the values near the sediment dropped to 7.5 in late summer (not shown). These $\mathrm{pH}$ ranges are much larger in mesotrophic and even much more pronounced in eutrophic lakes.
Conductivity stayed around $300 \mu \mathrm{S} \mathrm{cm} \mathrm{cm}^{-1}$ at the beginning of the mixing period in early winter and increased subsequently in the still fully mixed water column to $330 \mu \mathrm{S} \mathrm{cm}^{-1}$, probably due to a massive input of ion rich water by the rivers in the rain period (see supplementary material, Fig. 2). Photosynthetic production during the summer months resulted in a drop of conductivity from 320 to 276 and $295 \mu \mathrm{S} \mathrm{cm} \mathrm{cm}^{-1}$ at $5 \mathrm{~m}$ depth in September 2006 and 2007, respectively, as a consequence of biogenic decalcification (first described in detail by Minder 1923; Wetzel 2001). Over the whole period, a trend towards increasing values and smaller summer depressions is indicated.

Secchi depth, an indicator of suspended particles in the surface near layers, oscillated between 1.3 and $3.2 \mathrm{~m}$ with the lowest value in November 2007 (see supplementary material, Fig. 1). At that time a several weeks long heavy rainfall period (Fig. 2) increased the amount of TSS in the rivers by erosion processes leading to high turbidities in the lake water and a reduced Secchi depth.

However, for accidental short rain events like the strong rainfall as in May 2007, the bimonthly sampling regime does not give sufficient resolution. The relationship between the turbidity and TSS in the lake profile and the turbidity measured at the inlet of the water treatment plant (WTP) with daily resolution is described later in more detail.

\section{Nutrients}

As evidenced from the oxygen dynamics during the summer stratification (Fig. 3b), the Bovilla Reservoir is an oligotrophic water body. This is confirmed by the concentrations of the main macronutrients, phosphorus and nitrogen.

Soluble reactive phosphorus (SRP) concentrations oscillated between 2 and $8 \mu \mathrm{g} \mathrm{L}^{-1}$ (Fig. 4a), with higher values mainly in winter and lower values in spring, indicating its consumption by growing phytoplankton biomass. Over the 2 years, a slightly decreasing tendency is visible, suggesting that part of the nutrient load may originate from decaying organic material and the soil submersed 10 years ago after the construction of the dam. We assume that almost no change had occurred in 
Fig. 3 Chemical data: Water temperature plot (a), oxygen concentrations (b) and chlorophyll concentrations (c) at different depths between May 2006 and May 2008 at station S1 of Bovilla Lake
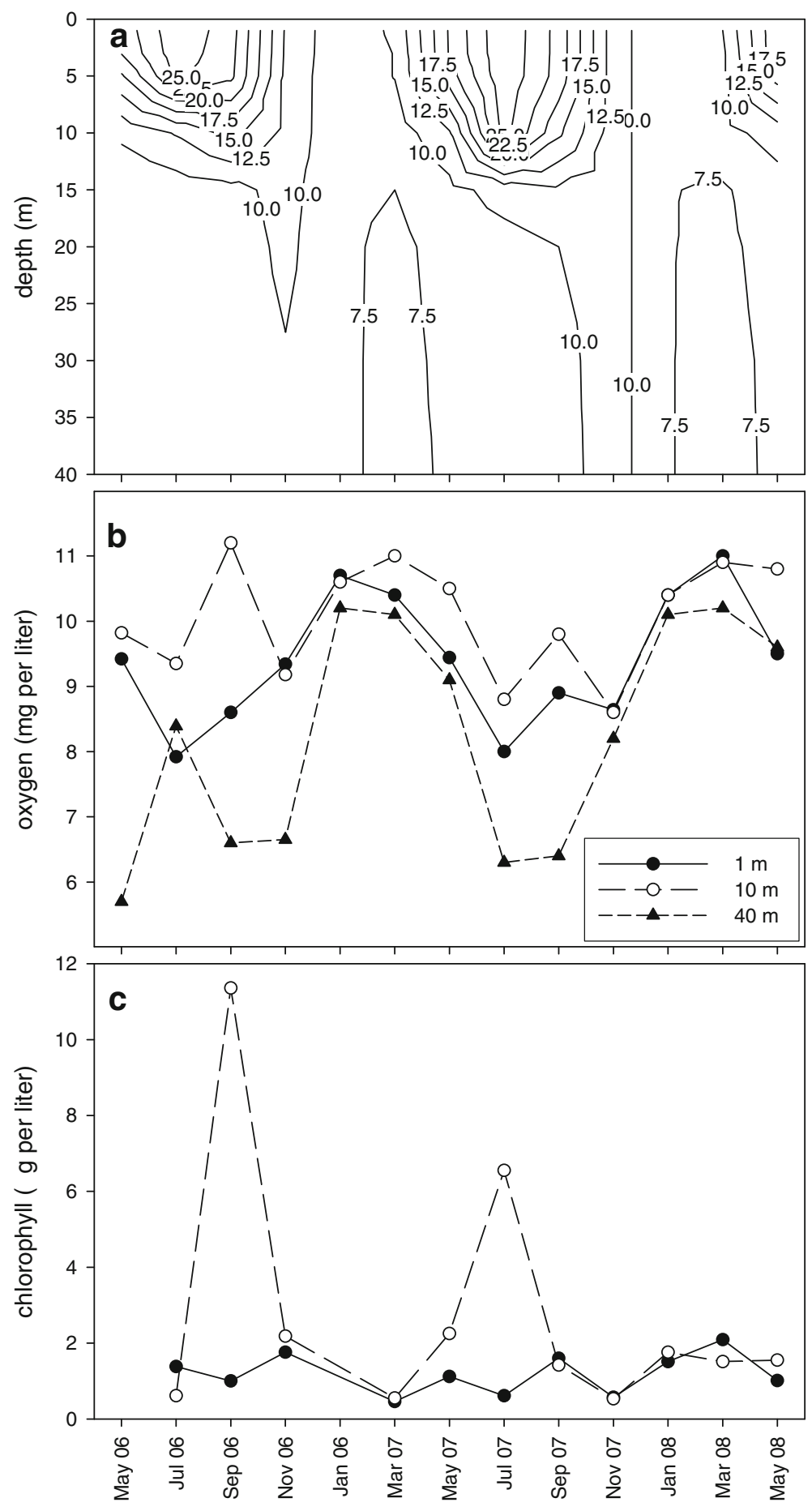

the drainage area concerning natural land cover, agricultural practices and other human activities.

Similar to the SRP dynamics, the nitrate concentration in the epilimnion decreased during spring as a consequence of algal growth from about $300 \mu \mathrm{g} \mathrm{L}^{-1}$ and remained in the 20 to $30 \mu \mathrm{g} \mathrm{L}^{-1}$ range until the start of the mixing in fall while in the hypolimnion the nitrate- $\mathrm{N}$ concentra- 
Fig. 4 Concentrations of soluble reactive phosphorus (a), nitrate (b) and ammonium (c) at different depths between May 2006 and May 2008 at station S1 of Bovilla Lake

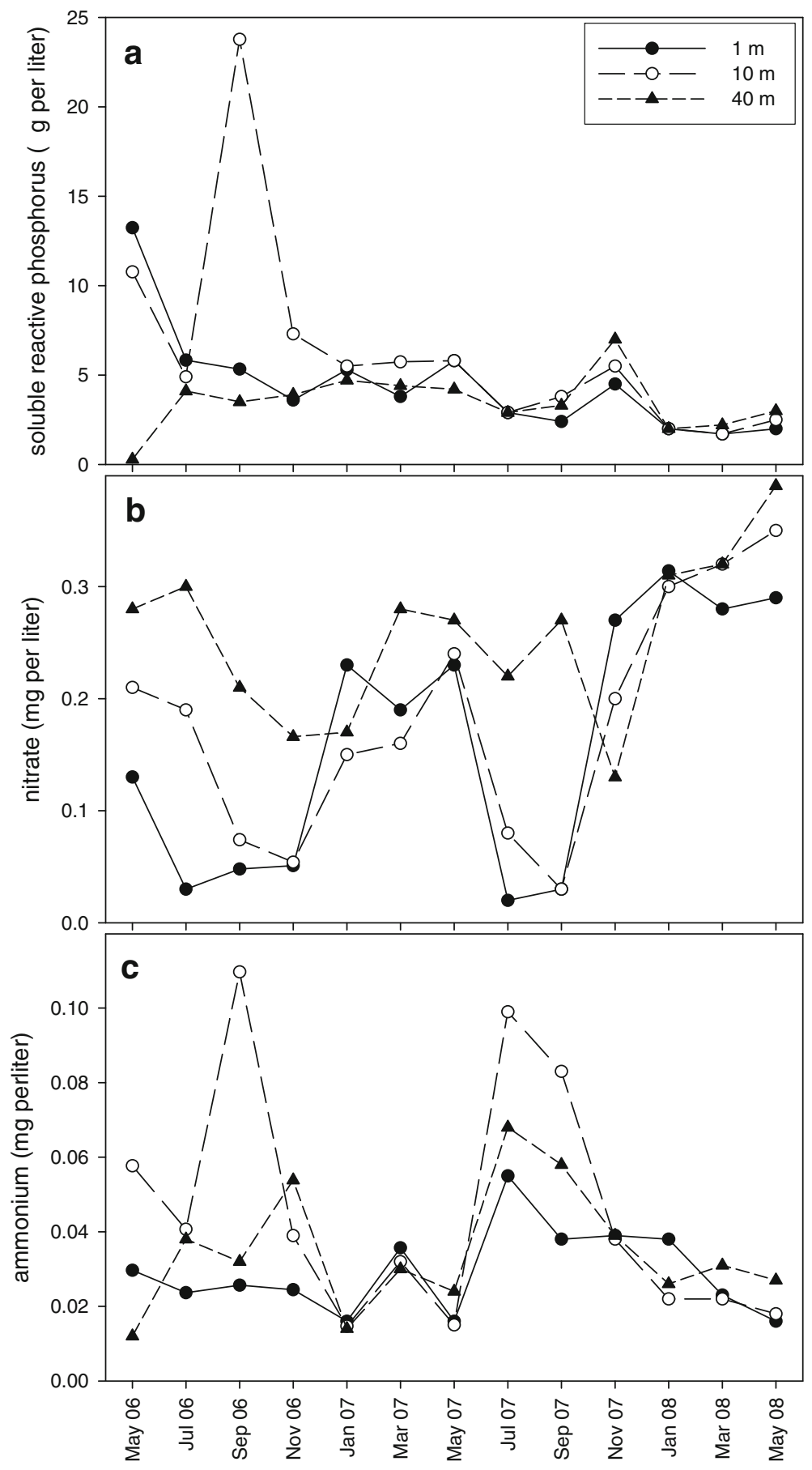

tion increased during the summer period (Fig. 4b). This indicates an $\mathrm{N}$-input by the tributaries and/or the release of organic $\mathrm{N}$ from the sediment and its subsequent nitrification.
Nitrite concentrations stayed at values below $3 \mu \mathrm{g} \mathrm{L}^{-1}$, and increased slightly during the mixing periods, but these concentrations had no influence on the N-budget of the lake (not shown). 
Ammonium-N concentrations were practically identical in the whole water column during the mixing periods (approximately $30 \mu \mathrm{g} \mathrm{L}^{-1}$ ), while the values varied significantly during stratification, similar to the other nutrients (Fig. 4c; minima between 10-20 $\mu \mathrm{g} \mathrm{L}^{-1}$ ). In summer 2007 , higher values were observed not only in the bottom water where the oxygen concentration had dropped by about $50 \%$, but also at 5 to $10 \mathrm{~m}$ depth probably due to rapid decay processes of biomass within the thermocline.

\section{Photosynthetic pigments}

The chlorophyll a concentration stays at low values of $2 \mu \mathrm{g} \mathrm{L} \mathrm{L}^{-1}$ for most parts of the year. In both years a single maximum in summer-early fall with values of up to $12 \mu \mathrm{g} \mathrm{L}^{-1}$ is reached (Fig. 3c). Typically the highest chlorophyll concentrations in summer were found at the highest algal densities in $10 \mathrm{~m}$ depth (Fig. 6).

\section{Phytoplankton}

In total, about 150 taxa of microscopic algae were determined within the phytoplankton of the Bovilla Reservoir during 2006 to 2008 (see supplementary material, Table 1); however, only a few species contributed to the major part of the algal biomass (Table 2). Centric diatoms (Bacillariophyta, Centrales) from the genus $C y$ clotella were the most frequent, mainly $C y$ clotella commensis; these amounted for most of the year to more than $90 \%$ of the plankton cells. Among the other groups, the Cryptomonads were the most abundant, represented by species of Cryptomonas and Rhodomonas. Although the data from 1998 to 2002 are incomplete, as samples were taken occasionally only from surface water and then counted using a Sedwick-Rafter chamber of $1 \mathrm{~mL}$, the same centric diatoms were dominant already in 2001. In contrast, a single sample from 1998 had a completely different species composition with a massive presence of the Dinoflagellate Ceratium hirundinella and equal numbers of the pennate diatoms Navicula sp. and Rhopalodia sp. (Bacillariophyta, Pennales; see supplementary material, Fig. 3). At that time, the lake had reached the present shoreline and was just completely filled.

When the cell numbers are integrated over the full water column, the succession shows the extremely strong dominance of Cyclotella sp. for 2006 and 2007, while in January 2008, Cryptomonas and Rhodomonas surprisingly outcompeted the total
Table 2 List of phytoplankton taxa collected in the Bovilla Reservoir during 1998 to 2002 and 2006 to 2008 with a frequency of more than 20 cells $\mathrm{mL}^{-1}$ found once in any depth (x) and indication of occasional presence of the species (o)

\begin{tabular}{|c|c|c|c|}
\hline & & 1998 to 2002 & 2006 to 2008 \\
\hline Bacillariophyceae - Centrales & Cyclotella sp. (C. commensis) & $\mathrm{x}$ & $\bar{x}$ \\
\hline \multirow[t]{7}{*}{ Bacillariophyceae - Pennatae } & Achnanthes minutissima & o & $\mathrm{x}$ \\
\hline & Brachisyra neoexilis & $\mathrm{x}$ & \\
\hline & Cymbella sp. & o & \\
\hline & Diatoma moniliformis & $\mathrm{x}$ & \\
\hline & Fragilaria sp. & $\mathrm{x}$ & $\mathrm{x}$ \\
\hline & Mastogloia smithii & $\mathrm{x}$ & \\
\hline & Navicula sp. & $\mathrm{x}$ & $\mathrm{x}$ \\
\hline \multirow[t]{3}{*}{ Dinophyceae } & Ceratium hirundinella & $\mathrm{x}$ & \\
\hline & Peridinium sp. & $\mathrm{x}$ & $\mathrm{x}$ \\
\hline & Peridiniopsis sp. & o & \\
\hline \multirow[t]{4}{*}{ Chlorophyceae } & Chlorococcus sp. & & $\mathrm{x}$ \\
\hline & Closterium $\mathrm{sp.}$ & $\mathrm{o}$ & \\
\hline & Spyrogira sp. & o & \\
\hline & Staurastrum tetraceum & $\mathrm{o}$ & \\
\hline \multirow[t]{2}{*}{ Cryptophyceae } & Cryptomonas sp. & & $\mathrm{x}$ \\
\hline & Rhodomonas minuta & & $\mathrm{x}$ \\
\hline Chrysophyceae & Dinobryon sp. & $\mathrm{x}$ & $\mathrm{x}$ \\
\hline Cyanophyceae & Anabaena sp. & $\mathrm{x}$ & $\mathrm{x}$ \\
\hline
\end{tabular}


number of the diatoms by a factor of up to 20. As the biovolume of the Cryptophyceae is estimated to be about 100 times greater than the one of the Cyclotella, the difference in the biovolume-related biomass becomes extreme; thus, the biovolume of Cyclotella dropped to 0.3\%. March 2008 showed the two groups in equal numbers but Cyclotella still amounted only for $3.4 \%$ of the biovolume. In the following fall, the sum of Cyclotella reached again up to 3,000 cells $\mathrm{mL}^{-1}$, resulting in 30 to 50 times more cells than the Cryptophyceae which, however, still contributed to about $70 \%$ of the total biomass (Fig. 5a, b).

Zooplankton covered Rotatoria with dominating species of Keratella and Polyarthra, Cladocera with species of Bosmina and Copepoda with Cyclops and Nauplius and Copepodit stages. Copepods dominated with up to 450 individuals per liter in the water column from 0 to $20 \mathrm{~m}$ most of the year over Cladocers with maximum numbers in July-September, while the number of rotifers only reached 70 individuals per liter between 0 to $20 \mathrm{~m}$ each year in May and three to 15 individuals per litre during the rest of the year (Fig. 5c). High numbers were found when the phytoplankton was rich in Cryptophyceae and low presence of Cyclotella.

The vertical distribution of the main phytoplankton groups differed through the year. This is illustrated for the seasons in Fig. 6.

Although the physicochemical data indicated a full circulation in winter the phytoplankton was stratified and only few cells were found below $20 \mathrm{~m}$ depth (Fig. 6b). Effects of wind on the water surface seemed temporarily minimal; this allowed developing vertical inhomogeneities. At this time, Cyclotella sp. was situated at $10 \mathrm{~m}$ depth but at only low numbers compared to spring and summer, while the Chrysophyceae, mainly Dinobryon sp., formed a broad layer between the surface and $20 \mathrm{~m}$ depth with 10 times greater cell concentration compared to Cyclotella, similar to the spring situation in Lake Zürich (Bleiker and Schanz 1989). In mid-summer (Fig. 6a), Cyclotella sp. was still stratified at $10 \mathrm{~m}$ depth, but its concentration had increased about 100 times. The Cryptophyceae remained close to the surface, but were now much decreased in numbers. Towards
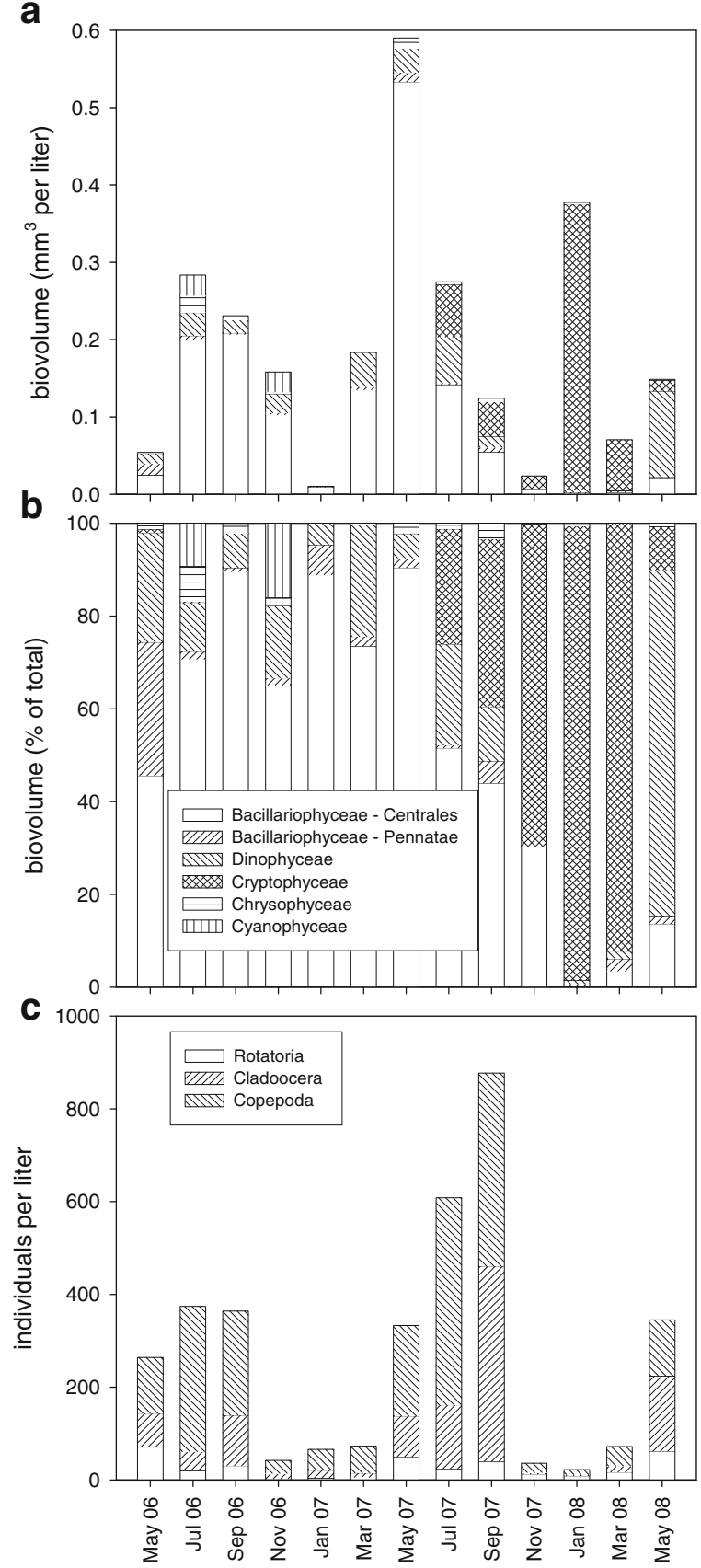

Fig. 5 Phytoplankton diversity and succession of algal plankton (a, b) and zooplankton (c) between May 2006 and September 2008 at station S1 of Bovilla Lake, presented (a) as biomass (biovolume of systematic categories per water volume), (b) as \% biomass distribution of the systematic categories and (c) as numbers of individuals per water volume, (a) and (c) are mean values within the water column between 0 and $15 \mathrm{~m}$ depth 


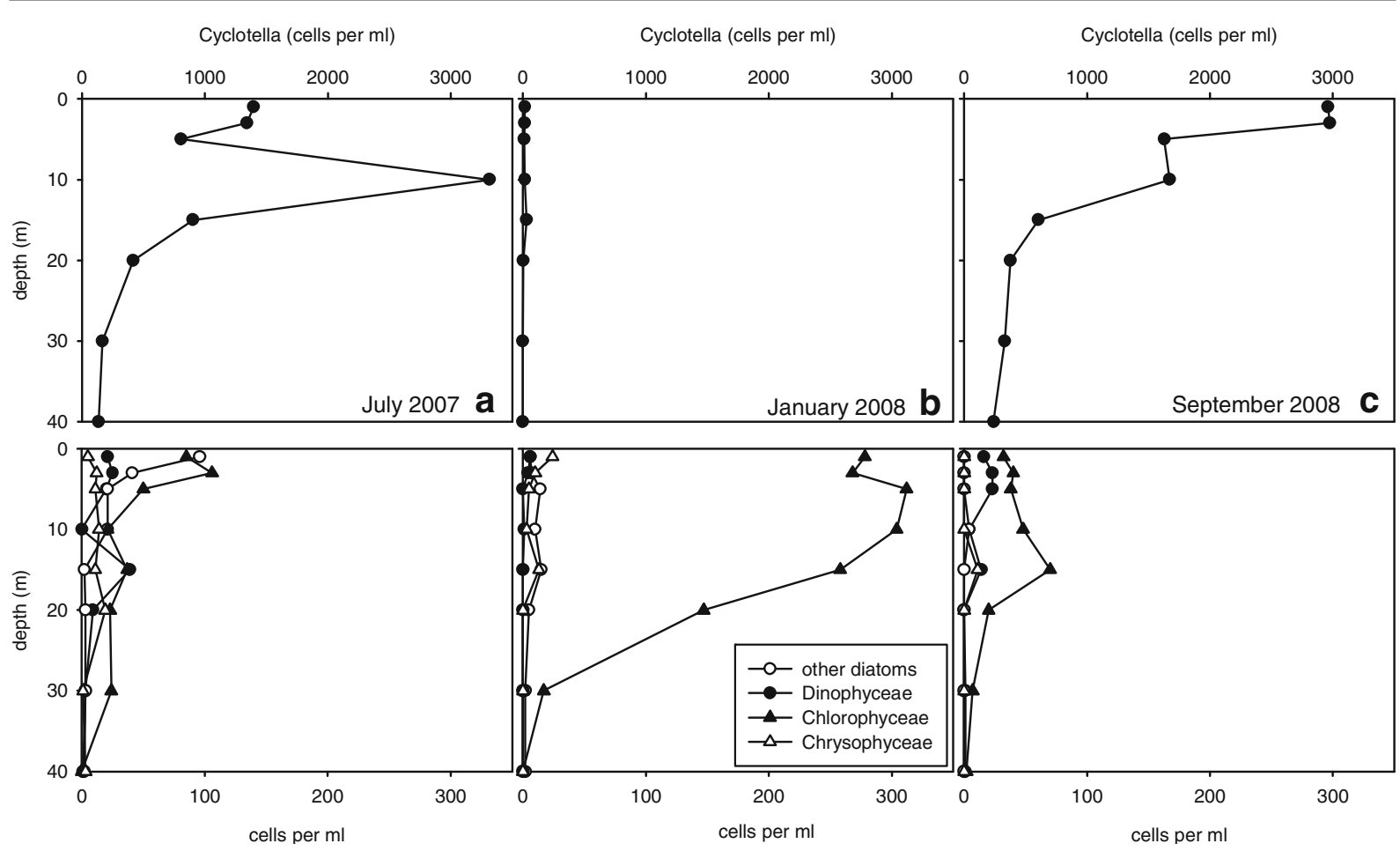

Fig. 6 Vertical distribution of Cyclotella (top) and other main algal groups (bottom)

fall (Fig. 6c) Cyclotella sp. was found closer towards the surface with similar high numbers as in summer, while the Cryptophyceae shifted to $15 \mathrm{~m}$ depth with lower numbers than in summer. Occasionally the Dinophyceae with mainly species of Peridinium were present in higher numbers. Peaks of high algal density at depths of more than $5 \mathrm{~m}$ might be clouds of sedimenting cells, they might be still alive and contain chlorophyll, but at the prevailing light intensity their photosynthetic activity would be insignificant (Sommer 1984a).

While no statistically sound differences were found in the depth profiles between the three sampling sites for the physicochemical parameters, the cell concentrations per area of Cyclotella sp. (cells $\mathrm{cm}^{-2}$ water surface) between surface and $10 \mathrm{~m}$ depth clearly differed. During summer to fall 2006 site 2 (S2) showed much lower values than the other sites. This might be because site 2 is situated close to the main tributary Terkuza, where the input of water and nutrients is strongly limited during the dry season (see supplementary material, Fig. 4).
Turbidity and suspended particles in the lake

The Secchi depth (see supplementary material, Fig. 1) is low in spite of a rather small biomass, due to the massive amount of suspended material brought in by the rivers. The number of particles reached up to $10^{6} \mathrm{~mL}^{-1}$ and their average size was about $0.4 \mu \mathrm{m}$ (Bachofen 2009). Algal cells recognized as autofluorescent particles by flow cytometry (due to chlorophyll fluorescence) amounted of $0.6 \%$ to $1.3 \%$ of the total of particles. Thus, a high input of suspended inorganic solids by the tributaries is the cause of the massive turbidity and diminished Secchi depth. This poses a great concern for the use of the Bovilla water for drinking purpose. In early winter and spring, heavy rainfall events usually change the inflowing rivers and brooks into torrents loaded with high amounts of suspended material which are brought into the lake (Figs. 7 and 8). This led to a pronounced turbidity peak in November 2007 even at the site near the dam, with increasing turbidity and total suspended solids values towards the lake 
Fig. 7 Turbidity at the inlet to the WTP from January 2006 to December 2008

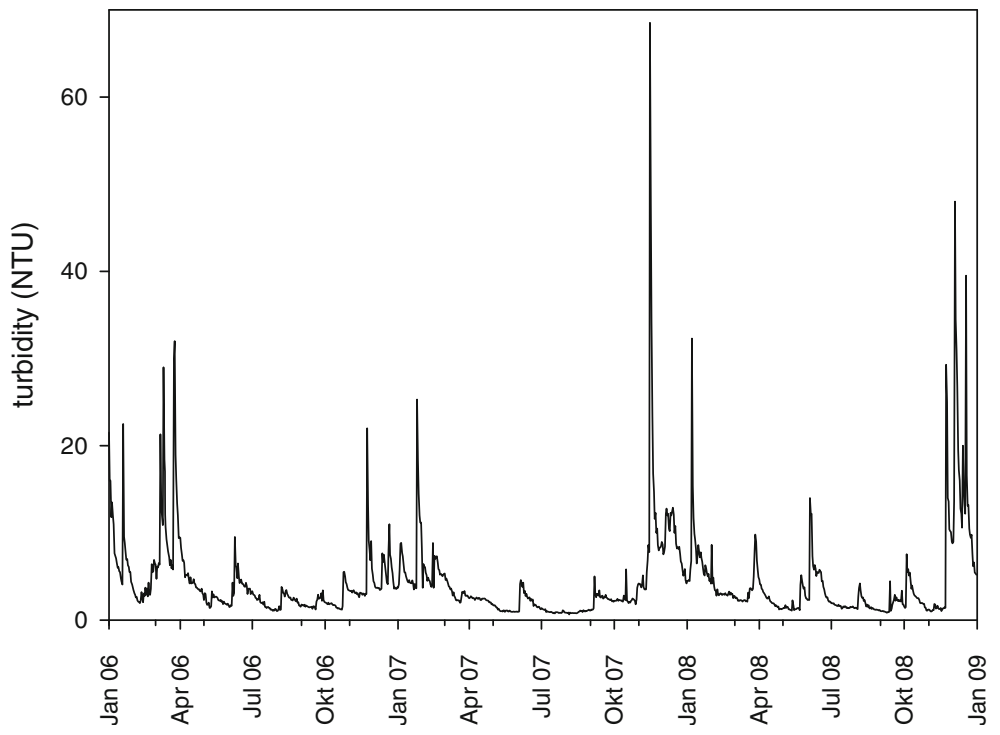

bottom. While the values for the epilimnion at $1 \mathrm{~m}$ depth increased from 3 to 9 NTU, the turbidity at 30 and $40 \mathrm{~m}$ depth jumped from 3 to 12 NTU or to 17 NTU, respectively. A large part of the suspended particles seems to sediment between the inlets of the tributaries to the sampling site S1 near the dam. The concentration of the TSS varied between 0.7 and $11.2 \mathrm{mg} \mathrm{L}^{-1}$. While during March to July the values stayed between 2 to $4 \mathrm{mg} \mathrm{L}^{-1}$ throughout the water profile, the rain event in November 2007 resulted in high turbidities, especially in the hypolimnion.
Not astonishing, there is a highly significant linear correlation between TSS and turbidity $\left(R^{2}=\right.$ 0.87 , see supplementary material, Fig. 5). As the turbidity is dependent on the properties of the particles, the close relationship confirms the homogeneous particle size distribution and material as indicated by the flow cytometry data. According to (Lewis et al. 2002) the slope of the regression line seems to vary widely between different aquatic systems, mainly depending on the origin of the particles and their size. Also, the Secchi depth data show a time course opposite to the turbidity,
Fig. 8 Profiles of TSS from July 2007 to January 2008 at station S1 of Bovilla Lake

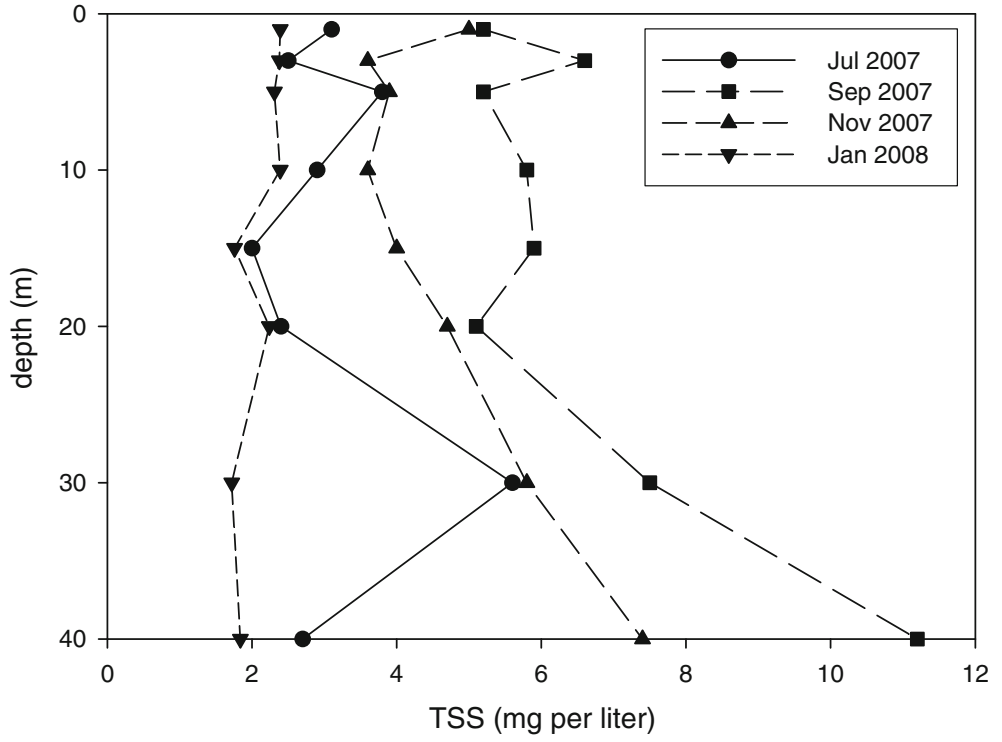


Fig. 9 Correlation between the bimonthly sum of rainfall and the observed TSS (mean value of depths measured between 0 and $40 \mathrm{~m}$ ) at each sampling date for the period July 2007 to May 2008 at station S1 of Bovilla Lake

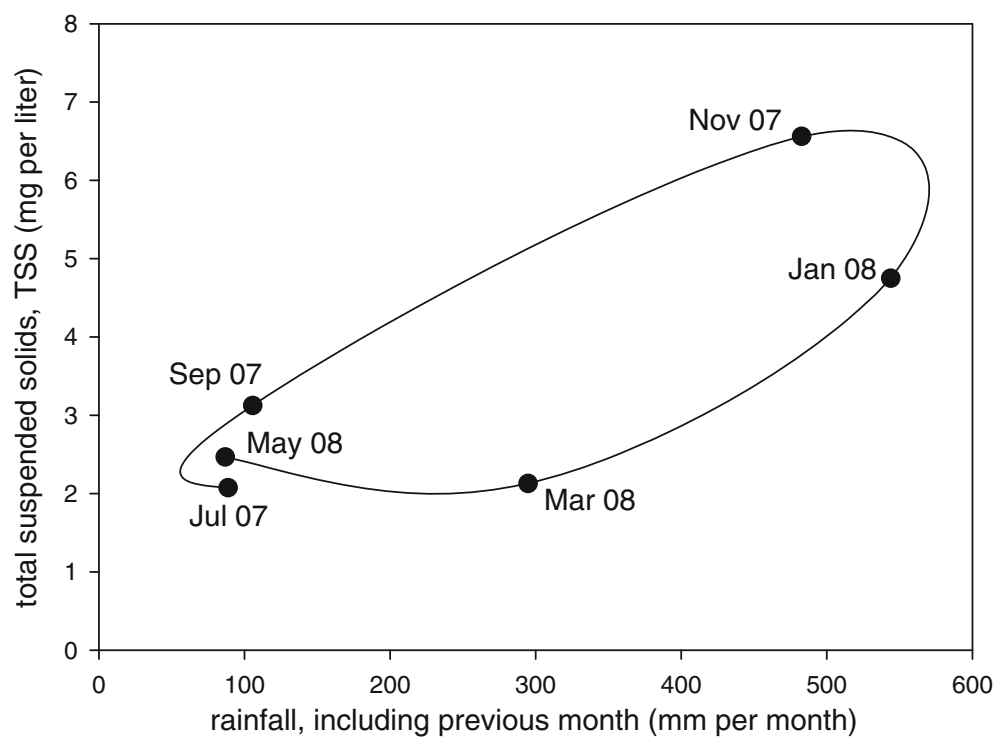

with a linear negative correlation $\left(R^{2}=0.73\right.$; not shown).

TSS plotted against the bimonthly sum of rainfall results also in a quasi linear dependence. However, as erosion during long rain periods is not proportional to particle transport, a hysteresis is observed (Fig. 9).

The hysteresis indicates that the water entering the lake at the beginning of the wet season is heavily loaded with material from erosion (November) but later with lasting heavy precipitation the TSS drops to low values reaching again in March values which are typical for the dry season.

Rain events occur mostly accidentally and are usually of short length; as a consequence turbidity at the site of the dam changes much slower and retarded. Data from the WTP which extracts the water near the dam at depths of 8 to $12 \mathrm{~m}$ below the lake surface indicate that heavy precipitation measured at the nearby Mount Dajti is seldom clearly mirrored in the turbidity at the lower end of the lake, opposite to the inlet of the main affluent Terkuza.

For example, November 13th of the year 2007 experienced a short but heavy rain event with a precipitation of $80 \mathrm{~mm}$. Turbidity at the inlet to the WTP increased drastically 2 days later, indicating that the rain covered a large part of the catchment area. Interestingly following rain peaks (November 25th to 30th) had no effect at all on the water turbidity, suggesting that these events were more local around Dajti Mountain and did not occur within the catchment area of the lake. In contrast, high turbidities occurred at other times when no rain events were recorded at Dajti Mountain. Therefore, these measurements can not be used for explaining turbidity events in the Bovilla reservoir in most cases.

\section{Discussion}

Bovilla Reservoir has been constructed to assure the drinking water supply of the fast growing capital of Albania, Tirana. As presented in this paper, Bovilla Reservoir is an oligotrophic to slightly mesotrophic aquatic system and judged on the water chemistry to be suitable as a drinking water source. Nutrient concentrations are low and biomass production is small based on the nutrient balance. This led to small oxygen production in the epilimnion and little depletion in the hypolimnion (above all in the layers close to the sediment surface) during the summer stagnation period. However, there are two important issues for the quality of the water for drinking water purpose as well as for the limnology of the lake: The high content of inorganic material transported into the lake by the main tributaries, especially by the Terkuza River and the occasional presence of undesirable smell 
and taste of the water (Cullaj and Bachofen 2009). Identification of these nuisance compounds and their sources has not been achieved so far.

\section{Turbidity}

It has been shown before that many Albanian rivers originating in the mountainous part of the country carry high amounts of suspended solids (TSS), up to $500 \mathrm{mg} \mathrm{L}^{-1}$ (e.g. Shkumbini, Miho et al. 2005). TSS numbers especially for Terkuza River are not available. However, in the lake, values of more than $10 \mathrm{mg} \mathrm{L}^{-1}$ were found near the lake sediment. Larger particles will sediment in the Northern part of the lake near the inflow of Terkuza, but as demonstrated by the Secchi depth, the turbidity and the concentration of TSS, fine particles remain in the water column during their transport from the inlet to the dam and finally end up in the WTP (Fig. 8). The input of solid materials into the lake has led within 10 years to an important reduction of the lake volume, the depth at site $\mathrm{S} 1$ raised from originally about $60 \mathrm{~m}$ to around $45 \mathrm{~m}$. The sediment at site $\mathrm{S} 1$ is white and of fine clay consistency. For comparison, colloidal particles have been studied in alpine lakes in Switzerland. In Lake Brienz, turbidity covered values between 0.7 and 5.6 FTU and the TSS amounted for 3.5 to $4.7 \mathrm{mg} \mathrm{L}^{-1}$ with particles of a size similar to Bovilla (Chanudet and Filiella 2007, 2008). Up to $97 \%$ of the particles brought in by the main river Aare are deposited by settling in the lake. With a high turbidity similar to Bovilla the euphotic depth, $z_{\mathrm{eu}}$, reached $7 \mathrm{~m}\left(z_{\mathrm{eu}},=\right.$ the depth at $1 \%$ of the subsurface light intensity).

The measurement of the turbidity in a water sample is an approximation of the amount of suspended material and less laborious than the estimation of TSS. The relationship depends on several factors including the size and shape of the particles and their density. Turbidity is a standard tool in stream sampling programs, but it is also useful for estimating TSS in lakes, particularly in reservoirs, since the lifetime of a reservoir depends upon how fast the main basin behind the dam is filled with inflowing sediments from the tributary streams. In many mid-European lakes (e.g. Lake Zürich, Lake Neuchâtel), the major source of turbidity is the phytoplankton, while only at the estuary of rivers, clay and silt particles from erosion and organic detritus become important. For Terkuza and many other rivers in Albania, the rising flow rates during heavy rain periods increase the amount of particles in the water. This will modify light penetration, cause the lake to fill faster, and show great impacts on the lake biology. Reduced light penetration diminishes algal and macrophyte growth and thus alters the food web. While algal turbidity varies seasonally and with depth, inorganic particles from the watershed vary more in response to hydrological events such as storms and snow melt. TSS is a parameter that directly relates to land uses in the watershed. Watershed development and poor land use practices cause increased erosion, transfer more organic matter and nutrients into the lake, all of which positively affect the concentration of the TSS, a phenomenon observed worldwide (Lenhart et al. 2010). Furthermore, a high TSS adds costs to the treatment of the water to be used as drinking water since the turbidity must be fully eliminated prior to disinfection and use.

A linear relationship between turbidity and TSS has been repeatedly described (Gippel 1995; Lenhart et al. 2010); with varying slopes between different aquatic systems. On one side, readings differ between instruments as well as between rivers with slopes between 1.01 and 2.06 for different creeks in Wisconsin (Fink 2005; Randerson et al. 2005) and 0.58 and 2.94 in California (Lewis et al. 2002).

Also in Bovilla, TSS concentrations follow the rise and fall of the rain events, but as soil saturation and erosive processes vary with continuing rainfall, a distinct hysteresis results between TSS and the bimonthly sum of the precipitation (Fig. 9).

\section{Production limiting factors and lake biology}

Phosphorus is proposed as the limiting nutrient for many mesotrophic and oligotrophic lakes. In the epilimnic layer of these lakes, its concentration is in general near the detection limit during the stagnation period whereas the inorganic nitrogen (sum of nitrate, nitrite and ammonium) remains e.g. in Lake Zürich above $200 \mu \mathrm{g} \mathrm{L}^{-1}$ (Gammeter 
et al. 1997). In Bovilla Lake, the phosphorus concentration (as SRP) never dropped below the detection limit of $1 \mu \mathrm{g} \mathrm{L}^{-1}$ (Fig. 4a). The single peak in September 2006 which is also seen in the ammonia might be due to a local weather event. Nutrients are often bound to colloids and particles and slowly released to be taken up by the plankton. It is known that the turbid Albanian rivers are heavily loaded with phosphates (e.g. Shkumbini with 30 to $375 \mu \mathrm{g} \mathrm{L}^{-1}$, Karamelo and Lazo 2008); this leads to phosphate concentrations in the sediment of Bovilla Lake of up to $450 \mu \mathrm{g} \mathrm{g}^{-1} \mathrm{~d}$.w. (Vallja et al. 2008). That the particulate fraction is a reservoir of certain nutrients is furthermore supported by a strong correlation between turbidity and the iron concentration in the water (see supplementary material, Fig. 6).

The inorganic nitrogen concentration reached occasionally values below $50 \mu \mathrm{g} \mathrm{L} \mathrm{L}^{-1}$ (July/August 2006 and July/August 2007, Fig. 4b). As discussed by Sterner (2008) nitrogen and phosphorus might have co-limited growth. In nutrient-poor lakes, also light may become limiting (Karlsson et al. 2009), especially at the high density of inorganic particles found in Bovilla Lake. Another element regulating growth and population density especially of the diatoms is silicon (Sommer and Stabel 1983). It is assumed that with the high concentrations of inorganic particles and colloids which are replenished continuously with every rainfall in the catchment, that silicon is not limiting the development of Cyclotella in Bovilla Lake.

The dominating plankton species, C. commensis, peaked during summer 2006 and 2007 concerning cell numbers and biovolumina, but starting with July 2007 and in 2008, the larger Cryptophyceae and Dinophyceae measured as biomass were fully outcompeting the small diatoms (Fig. 5). Pulses originating from the tributaries as a consequence of heavy rain events may have changed growthlimiting factors and disturbed equilibrium conditions (Sommer 1984b). Most of the time Cyclotella showed two maxima in the depth profiles, one close to the surface, and the other between 10 and $15 \mathrm{~m}$ depth, the latter often larger than the first one (Fig. 6). Compared to Lake Brienz where a similar Secchi depth of $2 \mathrm{~m}$ corresponded to less than $7 \mathrm{~m}$ euphotic zone (Finger et al. 2007), the algal population at 10 to $15 \mathrm{~m}$ in Bovilla would not be able to grow. It is assumed that Cyclotella sp. located below $10 \mathrm{~m}$ is slowly passively sinking out of the productive layer. However, it must be kept in mind that small diatoms have a very low light compensation point in many environments and a high efficiency for growth under low irradiation conditions (Ikeya et al. 2000; McMinn et al. 2000; Hawes and Schwarz 1999; Popovich and Gayoso 1999; Geider et al. 1986).

The plankton composition during 2001 and 2002 did not differ greatly from the period 2006 to 2008, with the dominating C. commensis and low cell numbers in winter (Fig. 5 and supplementary material, Fig. 3). This contrasts to the early single sample of 1998 consisting of a large biomass of pennate diatoms and Dinophyceae, but lacking centric diatoms.

Now after 10 years since the impoundment of the lake, we see a repeating annual cycle with the appearance of the dominant $C$. commensis in spring, staying with high numbers usually until the begin of the fall circulation. Still, it seems that a biological equilibrium has not been reached so far. Interferences by high water (disturbant hypothesis) and the low nutrient level should slow down the massive development of single species and rather stimulate algal biodiversity. On the other hand, turbulences in water with a high content of particles will create shearing forces, destroying fragile cells lacking sturdy envelopes and thus give diatoms a higher chance for survival. Occasional strong rain events, which may even force the lake management to massively dispose excess water as in April 2006, will lower the stability and delay the process towards a stable state. The low biomass observed in May 2006 may just be the results of a temporarily shortened residence time. Such weather-dependent disturbances are also observed in many seemingly stable aquatic systems.

Biological spring events with a peak biomass of Cyclotella sp. have been increasingly observed in many freshwater habitats in the Northern hemisphere. They cannot be explained with rising eutrophication but rather by climatic warming (Rühland et al. 2008; Thackeray et al. 2008). The situation of Bovilla Reservoir in these days with a low plankton biodiversity may present the final state to which lakes will arrive with continuing global warming. 
In temperate holomictic lakes r-strategist, often small diatoms develop regularly in spring with increasing light intensities and at the expense of the accumulated nutrients after the winter period. This is usually followed by a clear water period and later by larger plankton cells growing slowly as K-strategists. This was not the case in Bovilla Reservoir. C. commensis was dominating with about 1000 cells $\mathrm{mL}^{-1}$ in almost all seasons except shortly in winter 2006/2007 and later for a long winter-spring period in 2008. A bloom was observed in May 2007. The absence of large slow growing cells during 2006 until May 2007 points to a continuing input of nutrients from the environment to sustain the growth of these small r-strategists. In contrast, the winter-spring period 2008 is dominated by the larger cells of Cryptomonas, Rhodomonas and Peridinium, while Cyclotella reappeared only in fall 2008.

Increase or dominance in small cell diatoms is often observed in lakes with increasing thermal stability and/or reduced transparency. During a long stratification nutrient supply from the hypolimnion is limited, a situation favoring cells with a high surface to volume ratio. Furthermore, a small cell size diminishes the sinking velocity, an important property in turbid water with a production layer limited in size. Large algae may rapidly sediment out of the layer in which photosynthesis is possible while small diatoms profit from a robust shell, a high surface to volume ratio, low light adaptation and a low sinking speed. Such trends could be verified in Lake Tahoe (Winder et al. 2009). In Bovilla Lake the density stability during summer stratification becomes occasionally disturbed by the massive water inflow by the tributaries after strong rain events (Fig. 8), at least locally.

Periods of strong smell in the water occurred in both winters from November to March. These are the time spans of heavy rainfall and elevated turbidity. At the same time, both phosphorus and iron were present in higher concentrations, for $\mathrm{P}$ about a doubling, for Fe a four-time increase. A preliminary analysis of the volatile compounds extracted from the water indicated a sum of terpenes, but neither geosmin nor 4-methyl-borneol, the well-known smelling compounds in lake water were detected (Cullaj and Bachofen 2009).

\section{Conclusions}

The limnology of the Bovilla Reservoir has been studied bimonthly for 2 years to ascertain the quality of the water for its use as drinking water. The lake stratifies in summer and is fully mixed in winter. The watershed area has little direct effect on water quality; the steep shore area is of little influence on the water body. The residence time of around 1 year leads to a relatively stable chemistry and biology of the water. Pulselike precipitation events result in strong erosion and the tributaries bring large masses of particles and colloids into the lake. These particles carry adsorbed nutrients and limit light penetration into the epilimnion, resulting in biomass production controlled by light. Although the lake acts as a sediment trap, the particle concentration at the WTP needs a special filtration for drinking water quality.

Acknowledgements We express our highest gratitude to the Swiss National Science Foundation who kindly supported the work financially through SCOPES (JRP 7230111032/1). We also acknowledge the participating groups who worked mostly on the terrestrial watershed, its flora and vegetation, and on the human impact on Bovilla Reservoir: M. Mersinllari, L. Shuka, B. Draçi (University of Tirana) and F. Hoxha (Water Treatment Plant, Tirana).

\section{References}

Anonymous (1996). Impianti Hydrotek I Bovilles/Impianto iIdrotecnico di Bovilla (pp. 1-24). Tirana: Ministria e Ndertimit dhe Turizmit.

APHA (1988). Standard methods for the examination of water and wastewater (20th ed.), Washington DC, USA: American Public Health Association.

Bachofen, R. (2009). Concentration and size distribution of inorganic particles and cells in Lake Bovilla (Albania). In A. Miho, A. Cullaj, \& R. Bachofen (Eds.), Bovilla (Albania) a limnological study (pp. 181-190). Tirana.

Bleiker, W., \& Schanz, F. (1989). Influence of environmental factors on the phytoplankton spring bloom in Lake Zürich. Aquatic Sciences, 51, 47-58.

Chanudet, V., \& Filiella, M. (2007). The fate of inorganic colloidal particles in Lake Brienz. Aquatic Sciences, 69, 199-211.

Chanudet, V., \& Filiella, M. (2008). Size and composition of inorganic colloids in a peri-alpine, glacial flour-rich lake. Geochimica et Cosmochimica Acta, 72, 1466-1479.

Cullaj, A., \& Bachofen, R. (2009). Undesirable odor and taste events in Bovilla drinking water, relation to lake limnology and preliminary analysis. In A. Miho, A. 
Cullaj, \& R. Bachofen (Eds.), Bovilla (Albania) a limnological study (pp. 191-202) Tirana.

Finger, D., Bossard, P., Schmid, M., Jaun, L., Müller, B., Steiner, D., et al. (2007). Effects of alpine hydropower operations on primary production in a downstream lake. Aquatic Sciences, 69, 240-256.

Fink, J. C. (2005). The effects of urbanization on Baird Creek, Green Bay, Wisconsin (pp. 145). MS thesis, Green Bay: University of Wisconsin.

Floqi, T. (2007). Water quality and health-Albanian case. Proceedings of the 2nd French Serbian Summer School "Water quality control, from concept to action, October 7-13, 2007, Vrnjacka Banya, Serbia, 102-118. http:// water-environment.vin.bg.ac.yu/proceedings.

Gammeter, S., Forster, R., \& Zimmermann, U. (1997). Limnologische Untersuchung des Zürichsees (pp. 62). Zürich: Wasserversorgung Zürich.

Geider, R. J., Platt, T., \& Raven, J. A. (1986). Size dependence of growth and photosynthesis in diatoms: A synthesis. Marine Ecology, 30, 93-104.

Gippel, C. J. (1995). Potential of turbidity monitoring for measuring the transport of suspended solids in streams. Hydrologic Processes, 9, 83-97.

Gjata, A. (1997). Works resume in Bovilla Reservoir. Albanian Telegraph Agency (ATA) Tirana, Sept. 11 ${ }^{\text {th }}$, 1997. http://www.hri.org/cgi-bin/brief?/news/balakns/ ata/1997/97-09-11.ata.html\#11.

Gloyer, G. (2004). Albania. Buck: Bradt Travel Guides Ltd.

Hawes, I., \& Schwarz, A. M. (1999). Photosynthesis in an extreme shade environment: benthic microbial mats from Lake Hoare, a permanently ice-covered antarctic lake. Journal of Phycology, 35, 448-459.

Hutchinson, G. E. (1957). A treatise on limnology, Vol. I: Geography, physics and chemistry (pp. 1030). New York: Wiley.

Ikeya, T., Kashino, Y., Kudoh, S., Imura, S., Watanabe, K., \& Fukuchi, M. (2000). Acclimation of photosynthetic properties in psychrophilic diatom isolates under different light intensities. Polar Bioscience, 13, 43-54.

INSTAT (2010). Statistical Institute, Tirana, www.instat. gov.al.

Jüttner, F., \& Watson, S. B. (2007). Biochemical and ecological control of geosmin and 2-methylisoborneol in source waters. Applied and Environmental Microbiology, 73, 4395-4406.

Kabo, M. (Ed.) (1990-91). Physical geography of Albania. (Vol. I pp. 400 (1990), Vol. II, pp. 590 (1991)). Tirana: Albanian Academy Science.

Karamelo, P., \& Lazo, P. (2008). Shkumbini river water quality estimation, based on physico-chemical parameters and nutrient concentrations. Proceedings International Conference on biological and environmental Sciences. (pp. 684-687) Tirana.

Karlsson, J., Byström, P., Ask, J., Ask, P., Persson, L., \& Jansson, M. (2009). Light limitation of nutrient-poor lake ecosystems. Nature, 460, 506-509.

Lenhart, C. F., Brooks, K. N., Heneley, D., \& Magner, J. A. (2010). Spatial and temporal variation in suspended sediment, organic matter, and turbidity in a Minnesota prairie river: implications for TMDLs. Environmental Monitoring and Assessment, 165, 435-447.

Lewis, D. J., Tate, K. W., Dahlgren, R. A., \& Newell, J. (2002). Turbidity and total suspended solid concentration dynamics in streamflow from California oak woodland watersheds. USDA Forest Service Gen. Technical Report PSW-GTR-184, (pp. 107-118).

McMinn, A., Ashworth, C., \& Ryan, K. G. (2000). In situ net primary productivity of an Antarctic fast ice bottom algal community. Aquatic Microbial Ecology, 21, $177-185$.

Miho, A., Cullaj, A., Hasko, A., Lazo, P., Kupe, L., Bachofen et al. (2005). Environmental state of some rivers of Albanian Adriatic Lowland. (pp. 267), Tirana.

Miho, A., Cullaj, A., Bachofen, R. (Eds.) (2009a). Bovilla (Albania) a limnological study. (pp. 348). Tirana.

Miho, A., Shuka, L., Cullaj, A., \& Bachofen, R. (2009b). Environmental analyses of Bovilla watershed (Albania)an overview. In: A. Miho, A. Cullaj, R. Bachofen (Eds.) Bovilla (Albania) a limnological study. (pp. 11-46) Tirana.

Minder, L. (1923). Über biogene Entkalkung im Zürichsee. Verhandlungen Internationale Vereinigung Limnolologie, 1, 20-32.

Palombi, L., Villa, L., Divizia, M., Cenko, F., Siniari, V., Rotigliano, G., et al. (2001). Tirana, Albania: survey on drinking water quality and facilities. Water Science Technology, 43, 81-87.

Popovich, C. A., \& Gayoso, A. M. (1999). Effect of irradiance and temperature on the growth rate of Thalassiosira curviseriata Takano (Bacillariophyceae), a bloom diatom in Bahia Blanca estuary (Argentinia). Journal Plankton Research, 21, 1101-1110.

Randerson, T. J., Fink, J. C., Fermanich, K. J., Baumgart, P., \& Ehlinger, T. (2005). Total suspended solidsturbidity correlation in Northwestern Wisconsin streams. AWRA Section Meeting, Delavan Wisconsin. http://www.uwgb.edu/watershed/student/activities/ Presentations/AWRA_Randerson.pdf.

Rühland, K., Paterson, A. M., \& Smol, J. P. (2008). Hemispheric-scale patterns of climate-related shifts in planktonic diatoms from North American and European lakes. Global Change Biology, 14, 27402754.

Schulz, S., \& Dickschat, J. S. (2007). Bacterial volatiles: the smell of small organisms. Natural Products Reports, 24, 814-842.

Sommer, U. (1984a). Sedimentation of principal phytoplankton species in Lake Constance. Journal of Plankton Research, 6, 1-14.

Sommer, U. (1984b). The paradox of the plankton: fluctuations of phosphorus availability maintain diversity of phytoplankton in flow-through cultures. Limnology and Oceanography, 29, 633-636.

Sommer, U., \& Stabel, H. H. (1983). Silicon consumption and phytoplankton density changes of dominant planktonic diatoms in Lake Constance. Journal of Ecology, 71, 119-130.

Sterner, R. (2008). On the phosphorus limitation paradigm for lakes. International Revue of Hydrobiology, 93, 433-445. 
Thackeray, S. J., Jones, I. D., Maberly, S. C. (2008). Long-term change in the phenology of spring phytoplankton: species-specific responses to nutrient enrichment and climatic change. Journal of Ecology, 96, 523-535.

Utermöhl, H. (1958). Zur Vervollkommnung der quantitativen Phytoplankton-Methodik. Mitteilungen Internationalen Vereinigung Theoretische Angewandte Limnologie, 9, 1-38.
Vallja, L., Cullaj, A., \& Duka, S. (2008). Phosphate concentrations in the sediment of Bovilla Lake. Proceedings International Conference on biological and environmental Sciences, (pp. 640-644), Tirana.

Wetzel, G. W. (2001). Limnology-Lake and river ecosystems (pp. 1006). Oxford: Elsevier.

Winder, M., Reuter, J. E., Schladow, S. G. (2009). Lake warming favours small-sized planktonic diatom species. Proceedings of the Royal Society B, 276, 427-435. 